Marquette University

e-Publications@Marquette

4-1-2018

How Intense Policy Demanders Shape Postreform Politics: Evidence from the Affordable Care Act

Philip B. Rocco

Marquette University, philip.rocco@marquette.edu

Simon F. Haeder

West Virginia University

Accepted version. Journal of Health Politics, Policy and Law, Vol. 43, No. 2 (April 1, 2018): 271-304.

DOI. (C) 2018 Duke University Press. Used with permission. 
Marquette University

e-Publications@Marquette

\section{Political Science Faculty Research and Publications/College of Arts and Sciences}

This paper is NOT THE PUBLISHED VERSION; but the author's final, peer-reviewed manuscript.

The published version may be accessed by following the link in the citation below.

Journal of Health Politics, Policy and Law, Vol. 43, No. 2 (April, 2018): 271-304. DOI. This article is (C) Duke University Press and permission has been granted for this version to appear in ePublications@Marquette. Duke University Press does not grant permission for this article to be further copied/distributed or hosted elsewhere without the express permission from Duke University Press.

\section{Contents}

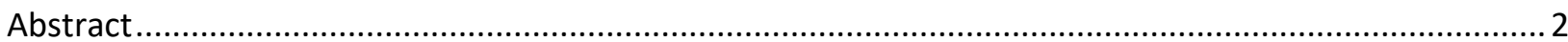

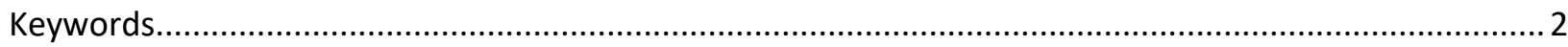

Parties, Intense Policy Demanders, and Postreform Politics......................................................... 4

Intense Policy Demanders and the Postreform Politics of the Affordable Care Act ...............................6

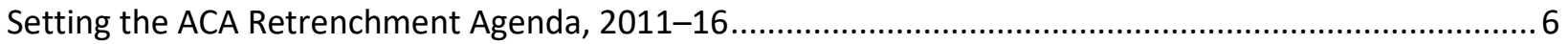

Intense Policy Demanders and the American Health Care Act................................................... 13

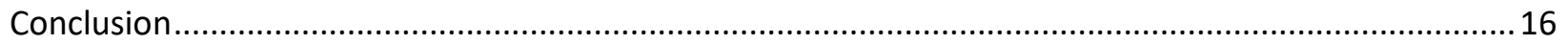

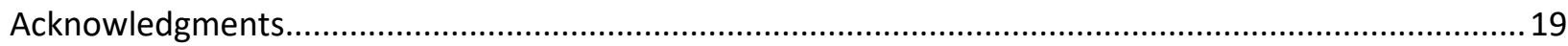

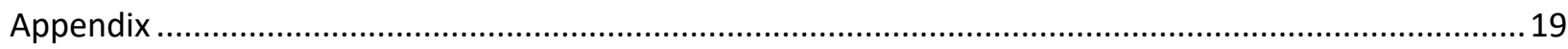

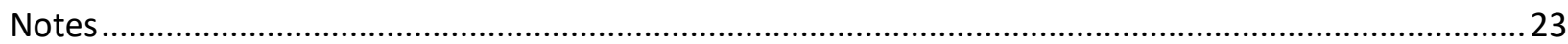

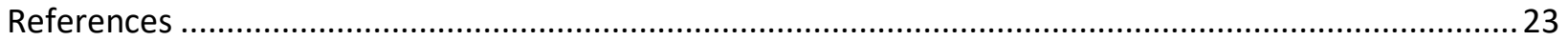




\title{
How Intense Policy Demanders Shape Postreform Politics: Evidence from the Affordable Care Act
}

\author{
Philip Rocco \\ West Virginia University, Morgantown, WV \\ Department of Political Science, Marquette University, Milwaukee, WI \\ Simon F. Haeder \\ Department of Political Science, John D. Rockefeller IV School of Policy and Politics, West Virginia \\ University, Morgantown, WV
}

\section{Abstract}

The implementation of the Affordable Care Act (ACA) has been a politically volatile process. The ACA's institutional design and delayed feedback effects created a window of opportunity for its partisan opponents to launch challenges at both the federal and state level. Yet as recent research suggests, postreform politics depends on more than policy feedback alone; rather, it is shaped by the partisan and interest-group environment. We argue that "intense policy demanders" played an important role in defining the policy alternatives that comprised congressional Republicans' efforts to repeal and replace the ACA. To test this argument, we drew on an original data set of bill introductions in the House of Representatives between 2011 and 2016. Our analysis suggests that business contributions and political ideology affected the likelihood that House Republicans would introduce measures repealing significant portions of the ACA. A secondary analysis shows that intense policy demanders also shaped the vote on House Republicans' initial ACA replacement plan. These findings highlight the role intense policy demanders can play in shaping the postreform political agenda.

\section{Keywords}

Affordable Care Act, ACA, Congress, parties, postreform politics

Less than a month after his election victory, president-elect Donald Trump announced that Rep. Tom Price (R-GA) would be his pick to serve as secretary of Health and Human Services. As chair of the House Budget Committee and a veteran of health care politics, Price hardly fit with the "outsider" brand Trump had crafted during the campaign. Nevertheless, he helped Trump signal his seriousness on a top domestic policy priority: Price had been a staunch critic of the Affordable Care Act (ACA) and the lead author of comprehensive legislation designed to repeal and replace it (Pear 2016). Five months after initiating repeal through the budget reconciliation process, Republicans in the House of Representatives 
had passed the American Health Care Act (AHCA), a bill the Congressional Budget Office (CBO) estimated would cause 24 million Americans to lose their coverage (CBO 2017a).

Republicans pushed the AHCA through the House at a rapid clip. The initial text of the bill was drafted in secret by House leadership. Committees held no hearings on the legislation. And while House

Republicans faced angry crowds at town-hall rallies, the prospect of electoral punishment seemed not to slow down the process. Indeed, a vote on the initial version of the legislation was scuttled only when conservative members of the House Freedom Caucus (HFC) signaled it had not done sufficient work at reducing spending and taxation (Alberta 2017).

If nothing else, the rapid pace of Republicans' efforts highlighted the ACA's severe political vulnerability (Kelly 2017). Indeed, Orren and Skowronek (2017: 164) argue that hypothesized "lock-in" effects from public policy enactments like the ACA are "more tentative" now than they were in the past. One source of the ACA's vulnerability, as several studies suggest, is the design of the law itself. Unlike Medicare and Social Security, the ACA is not a single program providing benefits to a coherent group (Oberlander and Weaver 2015). Rather, it is a compilation of multiple programs affecting a variety of groups. This contributes to political fragmentation among beneficiaries. Additionally, the benefits provided by the ACA are less visible and less traceable than past social programs. By relying on private insurers and state governments to carry out many of its core goals and delivering numerous benefits through the tax code, the ACA confuses and demobilizes beneficiaries, making them a less effective political constituency (Mettler 2011). Undergirding these problems is the fact that the designers of the ACA did not make extensive institutional investments to support the implementation of the law (Patashnik and Zelizer 2013).

Yet policy feedback alone cannot adequately explain why Republicans adopted the strategy of directly repealing and replacing the ACA. Rather, as recent scholarship suggests, postenactment politics is also deeply affected by changes in the partisan and interest-group environment that cannot be minimized by changes in policy design (Weir 2006; Maltzman and Shipan 2008; Berry, Burden, and Howell 2010). As we argue in this article, the absence of strong policy feedback mechanisms in the ACA does not explain how the policy solutions that defined the politics of "repeal and replace" emerged on the legislative agenda or why some solutions won out over others. Building on the work of Bawn et al. (2012), we argue that "intense policy demanders," mobilized activists within political parties that use their control of important electoral resources to shape the policy agenda, have defined the politics of repeal and replace in fundamental ways.

We begin by briefly discussing the current state of research on postreform politics and laying out our argument about the role of intense policy demanders. We then briefly discuss the ACA as an appropriate case for examining this phenomenon. Third, we consider the role of intense policy demanders in shaping the retrenchment agenda on the ACA with an original analysis of bill introductions in the House of Representatives between 2011 and $2016(N=730)$. Fourth, to illustrate how intense policy demanders shaped the politics of ACA retrenchment in 2017, we present the results of a secondary analysis of Republican support for the AHCA ( $N=237)$. These findings suggest the need for greater attention to the role of intense policy demanders in shaping postreform politics. 


\section{Parties, Intense Policy Demanders, and Postreform Politics}

Health reform is an inherently uncertain, even precarious, endeavor. Especially given the scale and complexity of the US health sector, policy makers may encounter profound cognitive challenges that make it difficult to predict the potential outcomes of reform. Design flaws have rendered programs like the Medicare Catastrophic Coverage Act politically unsustainable (Patashnik 2008; Himelfarb 1995). Emergent patterns of economic and social behavior have required significant adaptations to financing structures in major entitlement programs like Medicare (Oberlander 2007). Perhaps most important, turnover in the control of government has also opened programs like Medicaid to the risk of retrenchment (Rose 2013).

Thus, central questions in the study of health politics are how major reforms become politically entrenched and the conditions under which they can be reversed. Analyses of policy entrenchment have focused on how policy design helps construct large and politically vocal beneficiary constituencies and institutional structures that sustain policies over time through the process of policy feedback (Campbell 2011; Mettler 2011; Pierson 2000; Patashnik 2008). Yet policy designs can also be self-undermining. Reforms may be particularly open to retrenchment when they fail to create constituencies with material and ideational investments in program durability, or when administrative and financing structures are inadequate (Oberlander and Weaver 2015; Jacobs and Weaver 2015; Patashnik and Zelizer 2013).

While policy designs do indeed matter (Campbell 2011), recent scholarship has suggested that postenactment politics is also shaped by variables that cannot in practice be designed away. Several recent studies suggest that the durability of public policy and, consequently, the opportunities enjoyed by retrenchment advocates depend not on design features alone but also on the political conditions that surround enactment and implementation. As Weir (2006) perceptively argues, the organizational dynamics of parties and interest groups have an important effect on public policy. This point is borne out by several quantitative studies of legislative evolution in the United States. For example, strong, unified political coalitions are in a position to design policies in a way that entrench their benefits and protect them from retrenchment (Maltzman and Shipan 2008). Beyond enactment, partisan turnover in the control of Congress can significantly weaken the durability and size of major programs (Berry, Burden, and Howell 2010).

There is a need to further explore the link between partisan factors external to policy design and the politics of retrenchment, especially because polarization and partisanship have fundamentally reshaped the context in which members make decisions about public policy (Gerber and Schickler 2017). Studies by Maltzman and Shipan (2008) and Berry, Burden, and Howell (2010) show the link between partisan control of government and the durability of public policy over long spans of time. Yet by examining policy change itself as a dependent variable, these studies miss the process by which particular approaches to retrenchment gain priority on the legislative agenda. In practice, retrenchment can take a variety of forms, ranging from direct displacement of major social benefits to more subtle erosion over time (the so-called "death by a thousand cuts" strategy). Existing work on policy durability and gradual institutional change has sought to typologize and explain these variations (Hacker 2004; Mahoney and Thelen 2010; Patashnik 2008; Rocco and Thurston 2014). Nevertheless, such accounts tend to focus on explaining retrenchment outcomes rather than examining the process by which particular approaches to retrenchment become part of the legislative agenda. 
We argue that partisan dynamics can powerfully shape the politics of postenactment agenda setting. Specifically, organizational mobilization within party coalitions influences the prioritization of retrenchment on the legislative agenda, as well as how policy makers approach retrenchment itself. As Bawn et al. (2012: 571) suggest, parties in the United States can be understood as coalitions of "intense policy demanders," mobilized interest groups who seek to "capture and use government for their particular goals, which range from material self-interest to high-minded idealism." ${ }^{1}$

While party leaders and rank-and-file legislators are focused on winning and maintaining elective office, these groups are interested in specific policy goals. To achieve these goals, intense policy demanders intervene in politics by making elected officials their agents. Importantly, they seek to ensure that their allies and like-minded individuals are nominated and elected to office. Office seekers compete for contributions and other campaign resources held by these policy demanders. In turn, policy demanders require legislative commitments and strategically target resources to office seekers who demonstrate loyalty to those commitments. During the legislative process, intense policy demanders may offer other resources, such as drafting legislation and performing legislative research (Hertel-Fernandez 2014). When the demands of these groups depart from the interests of voters, elected officials may employ legislative procedures that limit the salience of their choices and may even take advantage of the complexity of public policy itself to create an "electoral blind spot."

Intense policy demanders can influence legislative action on retrenchment in several ways. Most clearly, they can leverage campaign contributions and other resources, such as endorsements, to make retrenchment a legislative priority (Bawn et al. 2012). Policy demanders also recruit nominees for legislative office who have ideological commitments that align with the goal of retrenchment (Broockman et al. 2017).

An important early indicator of policy demanders' success at influencing the retrenchment agenda is bill sponsorship. In contrast to other forms of position taking that are easily reduced to "cheap talk," bill sponsorship imposes costs on members-namely, the time it takes to generate draft legislation (Fenno 2003; Hall and Wayman 1990). As such, bill sponsorship provides policy demanders with a credible signal of preference intensity (Rocca and Gordon 2010). Even when legislation fails to pass a legislative chamber or to be enacted, bill sponsorship can help to set the agenda for future enactments (Woon 2009; Schiller 1995). To be sure, legislators may sponsor retrenchment legislation for reasons unrelated to the influence of intense policy demanders, such as their participation on relevant committees and subcommittees, seniority, overall legislative activity, and issue salience (Lazarus 2013; Woon 2009; Schiller 1995). Nevertheless, when intense policy demanders focus their energies on retrenchment, we expect their influence to take the form of bill sponsorship (Hall and Wayman 1990).

Group mobilization can also shape legislators' voting behavior (Bawn et al. 2012). In addition to recruiting like-minded individuals to Congress, intense policy demanders may exercise discipline on legislative voting through commitment structures such as pledges (Tomz and Van Houweling 2012) or by facilitating the creation of intraparty structures within Congress with the capacity to affect votes on relevant pieces of retrenchment legislation (Bloch Rubin 2013; DiSalvo 2012). 


\section{Intense Policy Demanders and the Postreform Politics of the Affordable}

\section{Care Act}

Because the role of intense policy demanders in shaping postreform politics is poorly understood, we leveraged a single-case study to create an analytical framework that future scholarship can test and expand upon (George and Bennett 2005). As Gerring (2004) suggests, single-case studies allow us to identify prima facie evidence of a causal link between variables. Such studies are especially useful when little is known about a social process or when "there is no identifiable suspect and the crime itself may be difficult to discern" (Gerring 2004: 350). To investigate our hypotheses in this case study, we employed process tracing, "the systematic examination of diagnostic evidence selected and analyzed in light of research questions and hypotheses posed by the investigator" (Collier 2011: 823).

Our empirical focus is postreform legislative opposition to the ACA. Undeniably, the ACA has been subject to significant and prolonged obstruction and opposition, which may make it an outlier among comparable cases in the literature (Haeder and Weimer 2015b; Béland, Rocco, and Waddan 2016). Partisan polarization over the law persists among both politicians (Bade 2015) and private citizens (DiJulio, Firth, and Brodie 2015). In particular, the law has encountered persistent and mobilized opposition from a coalition of Republican leaders at both the state and federal levels; conservativemovement organizations, including Americans for Prosperity (AFP); small-business organizations such as the National Federation of Independent Business (NFIB); and religiously affiliated employers, who oppose the ACA's contraceptive mandate (Haeder and Weimer 2013; Jacobs and Callaghan 2013; Béland, Rocco, and Waddan 2016; Jones, Bradley, and Oberlander 2013; Hertel-Fernandez, Skocpol, and Lynch 2016). Soon after the passage of the ACA, Republicans made the repeal of the law a top legislative priority (Béland, Rocco, and Waddan 2016).

Despite its status as an outlier, the ACA is an ideal case for analyzing the role of intense policy demanders at shaping the postreform political agenda (Jones, Bradley, and Oberlander 2013). Since the passage of the law in 2010, policy demanders within the GOP have had a unique opportunity for agenda setting. Republicans made significant, if not overwhelming, gains at the ballot box since the passage of the ACA. The results of the 2010 midterm elections gave Republicans control of the House of Representatives. They maintained these margins in the 2012, 2014, and 2016 elections. Additionally, the 2014 midterm elections gave Republicans control of fifty-four Senate seats. While these margins were inadequate for passing repeal legislation over a presidential veto, they enabled Republicans to continue to put significant repeal legislation on the table and force a presidential veto.

\section{Setting the ACA Retrenchment Agenda, 2011-16}

Organized groups played an important role in shaping congressional Republicans' strategy for attacking the ACA. Factional support for repeal and replacement came from several distinct sources. Arguably the most vociferous critics of the ACA were conservative ideological organizations such as Americans for Prosperity (AFP), the 501(c)(4) political advocacy group funded by Charles and David A. Koch (Skocpol and Hertel-Fernandez 2016). After the ACA's enactment, AFP campaigned against the law at all levels of government-organizing rallies against state expansion of Medicaid, funding over twenty thousand television advertisements opposing the law, and targeting vulnerable congressional Democrats with messages about the effects of their decisions on "Obamacare victims" (AFP 2017a; Harrington 2017). 
Groups affiliated with the Koch network also helped finance litigation to stop the implementation of various aspects of the ACA.

Yet throughout the implementation of the ACA, AFP kept its focus on legislation that repealed the ACA's major coverage provisions. In eight of fourteen "key votes" identified by the AFP between 2011 and 2016, the organization supported repealing ACA's coverage expansions in the individual marketplace (Title I) or through Medicaid (Title II) (see appendix table A1). AFP also sought to undermine the implementation of the ACA by supporting legislation repealing provisions of the ACA intended to stabilize insurance markets, such as the risk corridor program (AFP 2017b). Republican support for AFP's position on key votes related to ACA was nearly unanimous. Averaged across all key ACA votes, AFP received support from 98 percent of Republicans. During the same time period, 75 percent of Republicans on average supported AFP's position on key votes related to taxation. On budgetary legislation, AFP averaged 68 percent support from Republicans (see appendix table A2).

Employer groups also took numerous stands against the ACA. Small business associations urged repeal of the law's individual coverage mandate, which groups like the NFIB claimed would threaten smallbusiness owners' ability to operate their businesses. After the NFIB lost a constitutional challenge to the individual mandate in NFIB v. Sebelius (567 U.S. 519 (2012)), it continued to advocate for the repeal of the law through the legislative process (NFIB 2012, 2014, 2016).

Larger employers represented by the US Chamber of Commerce (USCC) also took a stand against the ACA's taxation provisions. ${ }^{2}$ Between 2011 and 2016, the USCC supported nine partial repeals, including bills that repealed taxes on insurers and medical device makers (USCC 2011a, 2011b, 2012a, 2012b, 2013a, 2013b, 2014a, 2014b, 2015a, 2015b, 2016). It supported three pieces of legislation that made substantive amendments to the ACA, such as those that eased the law's regulatory burdens on employers. The USCC identified only one key vote on a "major repeal" bill between 2011 and 2016. Yet in 2017, the USCC supported the House passage of major repeal legislation, citing, "critically important provisions" in the bill that would "repeal the health insurance tax, the medical device tax, and the tax on prescription medications" (USCC 2017).

Absent from major opposition to the ACA were health care provider organizations such as the American Medical Association. While these organizations had opposed prior efforts at health reform (Haeder and Weimer 2015a), the Obama administration and congressional leaders went to great lengths to incorporate them as stakeholders in designing the law (Beaussier 2012; Haeder 2012). During the regulatory process, insurers challenged the implementation of provisions such as new medical loss ratio standards; physicians and hospitals also expressed concerns about the law's cost-control measures (Béland, Rocco, and Waddan 2016). Nevertheless, while unsatisfied with various components of the ACA, these actors never became central to the repeal-and-replace coalition (see, e.g., American Medical Association 2017).

To analyze how intense policy demanders shaped Republicans' postreform agenda on the ACA, we constructed a data set of congressional legislation aimed at repealing the ACA or taking other adversarial actions toward the law between 2011 and 2016. Because Republicans consistently controlled the agenda of the House of Representatives during these years, we restricted our attention to that chamber. To identify potentially relevant legislation, we queried Congress.gov for all House bills introduced in the 112th, 113th, and 114th Congresses in which the ACA was mentioned either in the full text or in the summary prepared by the Congressional Research Service. After procedural measures and 
duplicates were removed, this yielded an initial search return of 659 bills. We then excluded all bills without a Republican sponsor $(N=107)$ and assessed the full text of the remaining bills $(N=552)$ for relevance (for a visual presentation of bill selection strategy, see appendix figure A1).

We included four types of bills in our final data set $(N=388)$. First, we included major repeals, defined as bills that (a) repealed major coverage provisions in Title I (including cost-sharing subsidies and premium tax credits), as well as provisions on which coverage depended (e.g., the individual mandate); (b) repealed Medicaid expansion provisions in Title II; or (c) delayed the implementation of major coverage provisions in the ACA. Second, we included partial repeals, defined as bills that left the ACA's major coverage provisions intact but repealed other provisions such as the medical-device tax or the Independent Payment Advisory Board. Third, we included substantive amendments, defined as bills that, while not repealing provisions, make significant changes to the ACA, such as revising provisions of the law applying to small businesses and creating opportunities for states to opt out of the ACA's regulatory requirements. Finally, we identified oversight and audit bills, defined as legislation that mandates greater scrutiny of the ACA's implementation, such as bills that require new reports by the Government Accountability Office. Examples of each bill type are presented in table 1.

Table 1 Examples of Bill Types Included in Data Set

\section{Major repeal}

- H.R. 2: Repealing the Job-Killing Health Care Law Act (Rep. Eric Cantor, R-VA-7, 1/5/11)

- H.R. 698: To deauthorize and rescind funding for the Patient Protection and Affordable Care Act and health-care-related provisions of the Health Care and Education Reconciliation Act of 2010 (Rep. Tim Scott, R-SC-1, 2/14/11)

\section{Partial repeal}

- H.R. 763: To repeal the annual fee on health insurance providers enacted by the Patient Protection and Affordable Care Act (Rep. Charles Boustany, R-LA-3, 2/15/13)

- H.R. 1076: To amend the Patient Protection and Affordable Care Act to provide for savings to the federal government by permitting pass-through funding for state-authorized public entity health benefits pools (Rep. Ralph Hall, R-TX-4, 3/12/13)

\section{Substantive amendment}

- H.R. 3679: To amend the Patient Protection and Affordable Care Act to prohibition on payment of bonuses and pay increases for executives of a state exchange funded through federal grants, and for other purposes (Rep. Cory Gardner, R-CO-4, 12/9/13)

- H.R. 3598: To amend the Patient Protection and Affordable Care Act to permit insurers to offer catastrophic coverage plans to anyone, and for other purposes (Rep. Jeff Fortenberry, R-NE-1, $11 / 21 / 13)$

\section{Oversight/audit}

- H.R. 3338: Certify It Act of 2014 (Rep. Stephen Lee Fincher, R-TN-8, 5/22/14)

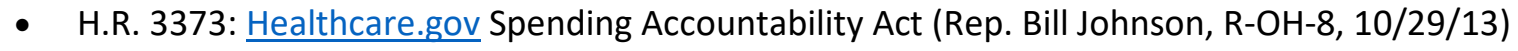


Source: Data collected by authors from Congress.gov

To explore the relationship between members' ideological preferences and agenda-setting activity related to the ACA, we transformed bill-level data into member-level counts of introduced legislation. Our member-level data set included all House Republicans who served at any time during the 112th, 113th, or 114th Congress ( $N=730$ observations of 330 unique members). Figure 1 presents the total number of bills of each type introduced in each session. With the exception of major repeal legislation, bill introductions of each type increased between the 112th and 113th Congresses and decreased between the 113th and 114th Congresses. There are a variety of potential reasons for this. Perhaps most plausible, gaining control of the Senate in the 2014 midterms enabled Republican leaders to generate a high-profile presidential veto of repeal legislation. As a result, the introduction of individual bills may have decreased as members consolidated their efforts around the repeal vehicle (Herzenshorn 2015).

\section{Figure 1}

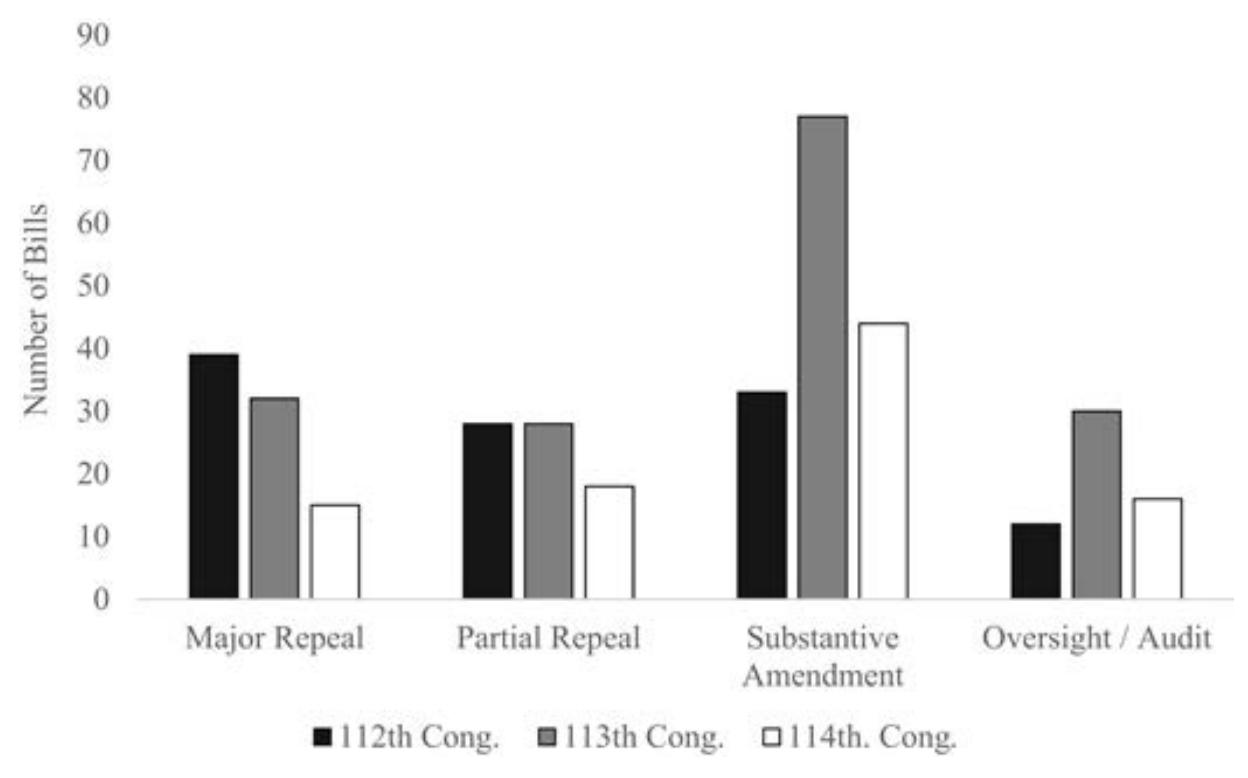

Bills Included in the Data Set, by Type and Session of Congress

Source: Data collected by authors from Congress.gov

In addition to recording the number of relevant bills a member introduced in each session, we collected data on two independent variables related to our argument. To measure business influence, we used data from the Center for Responsive Politics (www.opensecrets.org) to identify the amount of businesssector contributions members received in the election cycle prior to the Congress in which they served. To facilitate this analysis, we constructed the contributions variable by taking the log of the dollar values. We measure legislators' ideologies using first-dimension DW-NOMINATE scores (Poole and Rosenthal 2011). ${ }^{3}$

We also included several independent variables to capture how members' institutional position in Congress affects bill sponsorship (Schiller 1995; Woon 2009; Lazarus 2013). To account for the potential influence of institutional position, we included a measure of seniority, indicating the total number of 
terms the member has served in the House, including the Congress of observation (Stewart and Woon 2017). We also included several measures of members' participation and leadership of the two major referral committees for health policy, Energy and Commerce, and Ways and Means (see Lazarus 2013): an indicator variable for membership on either committee, an indicator variable for committee and subcommittee leadership of either committee, and indicator variables for membership on the health subcommittees of either committee. To code these variables, we collected data from the Congressional Directory. For both the seniority and committee variables, the expected relationship with bill introductions is positive.

Following Lazarus (2013), we also included a variable to capture members' proclivities toward bill writing in general, which we expected to be positively associated with bill introductions related to the ACA. The bill sponsorship variable captures the number of H.R.-designated bills for which each member in our data set was a prime sponsor, drawing on data from Congress.gov. As a proxy for what Woon (2009) describes as "problem severity" in health policy, a factor expected to increase the likelihood of bill introductions, we included the uninsured rate in each congressional district. For this measure, we included the percentage of the district's adult (eighteen- to sixty-four-year-old) population uninsured, as estimated by the Current Population Survey (2010 estimates were used for the 112th Congress, 2012 estimates for the 113th Congress, and 2014 estimates for the 114th Congress). Finally, to control for the effects of the legislative agenda in a given congressional session, we included indicator variables for the 113th and 114th Congresses.

Using this data set, we estimated several negative binomial models of bill introductions (table 2). The dependent variable in these models is the number of bills introduced by each member and considered by at least one congressional committee. In each model, we include the independent variables described above. All models employ standard errors clustered on individual legislators.

Table 2. Negative Binomial Regression Predicting Number of ACA-Related Bill Introductions by House Republicans, 2011-16

\begin{tabular}{|c|c|c|c|c|c|}
\hline \multirow[b]{2}{*}{ Variable } & \multicolumn{5}{|c|}{ Model } \\
\hline & $\begin{array}{l}\text { 1. All } \\
\text { bills }\end{array}$ & $\begin{array}{l}\text { 2. Major } \\
\text { repeals }\end{array}$ & $\begin{array}{l}\text { 3. Partial } \\
\text { repeals }\end{array}$ & $\begin{array}{c}4 . \\
\text { Amendments }\end{array}$ & 5. Oversight/audit \\
\hline Business contributions (Ln. \$) & $\begin{array}{l}0.24 \\
(0.08)^{* *}\end{array}$ & $\begin{array}{l}0.60 \\
(0.18)^{* * *}\end{array}$ & $\begin{array}{l}0.31 \\
(0.19)\end{array}$ & $\begin{array}{l}0.06 \\
(0.08)\end{array}$ & $\begin{array}{l}0.56 \\
(0.22)^{*}\end{array}$ \\
\hline NOMINATE & $\begin{array}{l}0.94 \\
(0.42)^{*}\end{array}$ & $\begin{array}{l}3.79 \\
(0.82)^{* * *}\end{array}$ & $\begin{array}{l}1.33 \\
(0.90)\end{array}$ & $\begin{array}{l}-0.35 \\
(0.62)\end{array}$ & $\begin{array}{l}-0.03 \\
(1.00)\end{array}$ \\
\hline Seniority & $\begin{array}{l}-0.00 \\
(0.01)\end{array}$ & $\begin{array}{l}0.04 \\
(0.02)^{+}\end{array}$ & $\begin{array}{l}-0.04 \\
(0.03)\end{array}$ & $\begin{array}{l}-0.02 \\
(0.02)\end{array}$ & $\begin{array}{l}0.00 \\
(0.03)\end{array}$ \\
\hline Committee member & $\begin{array}{l}0.47 \\
(0.18)^{* *}\end{array}$ & $\begin{array}{l}-0.45 \\
(0.42)\end{array}$ & $\begin{array}{l}0.88 \\
(0.34)^{*}\end{array}$ & $\begin{array}{l}0.75 \\
(0.25)^{* *}\end{array}$ & $\begin{array}{l}0.14 \\
(0.43)\end{array}$ \\
\hline $\begin{array}{l}\text { Health subcommittee } \\
\text { member }\end{array}$ & $\begin{array}{l}0.46 \\
(0.19)^{*}\end{array}$ & $\begin{array}{l}1.25 \\
(0.42)^{* *}\end{array}$ & $\begin{array}{l}0.23 \\
(0.33)\end{array}$ & $\begin{array}{l}0.37 \\
(0.26)\end{array}$ & $\begin{array}{l}0.52 \\
(0.44)\end{array}$ \\
\hline Committee leadership & $\begin{array}{l}0.08 \\
(0.20)\end{array}$ & $\begin{array}{l}-0.11 \\
(0.46)\end{array}$ & $\begin{array}{l}0.77 \\
(0.36)^{*}\end{array}$ & $\begin{array}{l}-0.22 \\
(0.30)\end{array}$ & $\begin{array}{l}0.05 \\
(0.48)\end{array}$ \\
\hline
\end{tabular}




\begin{tabular}{|c|c|c|c|c|c|}
\hline \multirow[b]{2}{*}{ Variable } & \multicolumn{5}{|c|}{ Model } \\
\hline & $\begin{array}{l}\text { 1. All } \\
\text { bills }\end{array}$ & $\begin{array}{l}\text { 2. Major } \\
\text { repeals }\end{array}$ & $\begin{array}{l}\text { 3. Partial } \\
\text { repeals }\end{array}$ & $\begin{array}{c}4 . \\
\text { Amendments }\end{array}$ & 5. Oversight/audit \\
\hline Sponsorship activity & $\begin{array}{l}0.04 \\
(0.00)^{* * *}\end{array}$ & $\begin{array}{l}0.03 \\
(0.01)^{* *}\end{array}$ & $\begin{array}{l}0.03 \\
(0.01)^{*}\end{array}$ & $\begin{array}{l}0.05 \\
(0.01)^{* * *}\end{array}$ & $\begin{array}{l}0.03 \\
(0.01)^{*}\end{array}$ \\
\hline Uninsured rate & $\begin{array}{l}0.01 \\
(0.01)\end{array}$ & $\begin{array}{l}-0.00 \\
(0.02)\end{array}$ & $\begin{array}{l}0.02 \\
(0.02)\end{array}$ & $\begin{array}{l}0.00 \\
(0.02)\end{array}$ & $\begin{array}{l}0.03 \\
(0.02)\end{array}$ \\
\hline 113th Congress & $\begin{array}{l}0.45 \\
(0.14)^{* *}\end{array}$ & $\begin{array}{l}-0.13 \\
(0.26)\end{array}$ & $\begin{array}{l}-0.07 \\
(0.29)\end{array}$ & $\begin{array}{l}1.02 \\
(0.23)^{* * *}\end{array}$ & $\begin{array}{l}0.89 \\
(0.36)^{*}\end{array}$ \\
\hline 114th Congress & $\begin{array}{l}-0.13 \\
(0.15)\end{array}$ & $\begin{array}{l}-0.90 \\
(0.31)^{* *}\end{array}$ & $\begin{array}{l}-0.37 \\
(0.30)\end{array}$ & $\begin{array}{l}0.43 \\
(0.25)^{+}\end{array}$ & $\begin{array}{l}0.22 \\
(0.40)\end{array}$ \\
\hline Alpha & 0.39 & 0.62 & 0.51 & 0.59 & 0.68 \\
\hline Log likelihood & -656.94 & -255.34 & -233.15 & -379.84 & -192.29 \\
\hline Observations (clusters) & $\begin{array}{l}730 \\
(330)\end{array}$ & $\begin{array}{l}730 \\
(330)\end{array}$ & $\begin{array}{l}730 \\
(330)\end{array}$ & $\begin{array}{l}730 \\
(330)\end{array}$ & $\begin{array}{l}730 \\
(330)\end{array}$ \\
\hline
\end{tabular}

Notes: Cell entries are coefficients from negative binomial regression with clustered standard errors in parentheses. ${ }^{+} p<0.10$, ${ }^{*} p<0.05,{ }^{* *} p<0.01,{ }^{* * *} p<0.001$, two-tailed tests

Model 1 predicts the overall number of bills introduced by a member of Congress. The results suggest support for our hypotheses. More conservative House Republicans (i.e., those with higher DWNOMINATE scores) and House Republicans with higher levels of business-sector contributions in the prior election cycle were significantly more prone to legislation that repealed or significantly altered the ACA. Membership on either the Energy and Commerce Committee or the Ways and Means Committee, as well as membership on health subcommittees of either committee, also had a positive and statistically significant relationship with bill sponsorship. House Republicans were more likely to introduce legislation related to the ACA when their overall level of bill sponsorship was higher. Finally, House Republicans were more likely to introduce such bills during the 113th Congress.

Because the results of negative binomial models cannot be straightforwardly interpreted, the middle column of table 3 presents marginal effects from model 1 . As table 3 suggests, a shift in the NOMINATE variable from its mean to one standard deviation above the mean increased the predicted number of bill introductions by 16 percent. When logged business contributions in the prior election cycle increase from the mean to one standard deviation above the mean, the number of bill introductions is predicted to rise by 53 percent. Membership on the Energy and Commerce Committee or Ways and Means Committee, as well as the health subcommittees thereof, increased the predicted number of bill introductions by 59 percent. Increasing the overall sponsorship activity from its mean to one standard deviation above its mean resulted in a 41 percent increase in bill introductions. All else equal, bill introductions increased by 53 percent during the 113th Congress. 
Table 3 Marginal Effects for Statistically Significant Variables in Models 1 and 2

\begin{tabular}{|c|c|c|c|}
\hline $\begin{array}{l}\text { Independent } \\
\text { variable }\end{array}$ & $\begin{array}{l}\text { Change in variable } \\
{\text { (from, to })^{\mathrm{a}}}\end{array}$ & $\begin{array}{l}\text { Model 1: predicted percentage } \\
\text { change in bill introductions }\end{array}$ & $\begin{array}{l}\text { Model 2: predicted percentage } \\
\text { change in major repeal introductions }\end{array}$ \\
\hline $\begin{array}{l}\text { Business } \\
\text { contributions (Ln. \$) }\end{array}$ & $11.41 \rightarrow 13.20$ & $53.13 \%$ & $281.82 \%$ \\
\hline NOMINATE & $0.48 \rightarrow 0.63$ & $15.63 \%$ & $72.73 \%$ \\
\hline Seniority & $4.57 \rightarrow 8.71$ & - & $18.18 \%$ \\
\hline Committee member & $0 \rightarrow 1$ & $59.38 \%$ & - \\
\hline $\begin{array}{l}\text { Health } \\
\text { subcommittee } \\
\text { member }\end{array}$ & $0 \rightarrow 1$ & $59.38 \%$ & $236.36 \%$ \\
\hline Sponsorship activity & $13.62 \rightarrow 22.94$ & $40.63 \%$ & $27.27 \%$ \\
\hline 113th Congress & $0 \rightarrow 1$ & $53.12 \%$ & - \\
\hline 114th Congress & $0 \rightarrow 1$ & - & $-63.64 \%$ \\
\hline
\end{tabular}

Note: We calculated marginal effects by shifting a given variable one standard deviation above the mean for continuous variables and from 0 to 1 for dichotomous variables. We held all other variables constant at their mean values or, for dichotomous variables, at their modal values.

Models $2-5$ in table 2 disaggregate bill introductions by type. Consistent with the idea that major repeal of the ACA was a legislative priority for intense policy demanders within the Republican Party, business contributions and ideology had a significant effect on major repeals. The third column of table 3 illustrates the marginal effects for model 2. The effects of both ideology and business contributions are accentuated here. An increase in the ideology variable from its mean to one standard deviation above the mean yields a 73 percent increase in the number of major repeals introduced. A similar increase in the contributions variable results in a 282 percent increase in the number of major repeals introduced. Among the variables associated with members' institutional position, membership on the health subcommittee of either Ways and Means or Energy and Commerce resulted in a 236 percent increase in the number of major repeal bills introduced.

Across the three other bill types we examined (partial repeal, amendments, and oversight/audit legislation), the effects of both ideology and business contributions were muted. We found no statistically significant relationship between ideology and these sorts of bill introductions; business contributions were statistically significantly related only to oversight and audit legislation. By contrast, variables such as committee membership and overall sponsorship activity had statistically significant relationships with members' sponsorship of both partial repeals and substantive amendments. 
We also estimated models that used an alternative measure of business contributions, restricted to the contributions of business associations (see appendix table A3). The results suggest that business association contributions have a similarly statistically significant effect on both bill introductions in general and major repeals. Reduced models that include only the NOMINATE and initial business contributions variables (see appendix table A4) yield results consistent with those in table 2.

\section{Intense Policy Demanders and the American Health Care Act}

As the evidence above suggests, intense policy demanders within the Republican Party spent the first six years of the ACA's life setting the stage for retrenchment. By the end of 2016, most Republican policy solutions in the legislative pipeline were not incremental adjustments to the ACA but proposals for the displacement of major sections of the legislation. Yet Republicans advanced proposals to repeal and replace the ACA's coverage expansions in the shadow of President Obama's likely veto. Thus, while these bills did set the agenda for what came next, they neither created serious electoral risks nor sparked major intraparty battles over legislative content. By contrast, the surprise election of Donald Trump in 2017 gave intense policy demanders a unique opportunity to push forward proposals for significant retrenchment to the ACA without the threat of a presidential veto that had existed during the Obama presidency. How did intense policy demanders influence the debate when legislative victory seemed within reach?

In a postelection interview, House Speaker Paul Ryan (R-WI) reported that repealing the ACA was a top legislative priority and that the party's strategy would be to "go big" and "go bold" (Ryan 2016). To observers around the country, Ryan's initial proposal for what would become the AHCA looked like drastic retrenchment (see, e.g., St. Louis Post-Dispatch2017; Lincoln Journal Star2017; Akron Beacon Journa/2017). The plan released by House Republican leadership in early 2017 eliminated the subsidies for the purchase of health insurance in the nongroup market, replacing them with age-based tax credits. For younger individuals, the effects of these repeals varied geographically: a twenty-seven-year-old with an annual income of $\$ 30,000$ would see annual costs rise by $\$ 2,000$ in Nebraska: the same individual would see them fall by $\$ 2,000$ in the state of Washington (Kaiser Family Foundation 2017). Yet for older individuals, average annual costs rose nearly everywhere. Under the AHCA, analyses released by the Kaiser Family Foundation suggested that a middle-income sixty-year-old couple would lose more than $\$ 8,000$ in premium tax credits compared to the Affordable Care Act (Cox, Claxton, and Levitt 2017).

The AHCA also made drastic changes to Medicaid, rolling back the ACA's expansion of the program by cutting reimbursement to states for individuals leaving the Medicaid rolls, resulting in a gradual but significant decline in the number of individuals covered by the program. The legislation further proposed eliminating Medicaid's entitlement status, converting it into a grant program in which states would either receive a per-capita allotment or a fixed-dollar block grant (CBO 2017a). In an analysis of the AHCA published on March 13, 2017, the CBO estimated the law would result in 24 million fewer individuals with insurance coverage in 2026 compared to current law (CBO 2017a). ${ }^{4}$

Yet for intense policy demanders within the Republican Party, the changes wrought by the AHCA were insufficient. Groups like the Koch-backed AFP and Heritage Action argued that the law was merely "Obamacare Lite" (Harrington 2017; Needham 2017). While the law's changes to Medicaid and tax subsidies allowed Republicans to eliminate the surtax on high-income taxpayers' net investment income, as well as other increases in payroll and excise taxes, far-right policy demanders argued that they did not 
go far enough. The major organizational proponent of this view within Congress was the House Freedom Caucus (HFC), a small but cohesive group of thirty-one House members that formed during the 2015 Republican congressional retreat. After Ryan released his initial plan, the HFC held an informal meeting in the Rayburn House Office Building and agreed to resist whipping efforts by House leadership and the White House (Bade and Dawsey 2017). Without the HFC's votes, House leaders agreed to withdraw the AHCA from consideration on March 24, 2017, just hours before a scheduled vote (Alberta 2017). HFC members leveraged this victory to extract concessions from House leaders.

In the weeks following the failed vote, leaders negotiated a compromise in the form of an amendment by Rep. Tom MacArthur (R-NJ). MacArthur's amendment allowed states to opt out of regulatory provisions in the ACA that required insurance plans to establish a set of essential health benefits and prevented the setting of premiums based on health status (Jost 2017). These provisions proved satisfactory to the HFC, whose members lined up behind the legislation. While moderates remained skeptical of the legislation, they lacked the resources for resisting whipping efforts. By contrast, AFP created a campaign fund for members of the HFC that promised to vote against the initial version of the AHCA. Thus, on May 4, after only a short floor debate and in the absence of a revised CBO score, House leaders shepherded the AHCA to a 217-213 victory, with twenty Republicans voting against final passage.

To explore how intense policy demanders shaped the passage of the AHCA, we constructed a data set examining House Republicans' support for the bill $(N=237)$. Our data set included two dependent variables. First, we collected data on a whip count published in the New York Times (2017b), taken several days prior to the canceled March 24 vote. Using these data, we constructed a binary variable that takes the value of 1 when a member reported their intention to vote yes on the legislation and 0 otherwise, including for members reporting uncertainty about their vote, leaning toward a no vote, or intending to vote no on the legislation. These data were collected after the initial CBO score of the legislation had been released, allowing members to identify the effects of the law on taxation, spending, and insurance coverage.

We then identified House Republicans' positions on the May 4 roll-call vote (New York Times2017a), which occurred after the introduction of the MacArthur amendment. We constructed a binary variable that takes the value of 1 when a member voted yes on the legislation and 0 otherwise. For the sake of consistency, we included in the data set all members who were present for the first scheduled vote on the AHCA and the actual May 4 roll call. Thus, our data set excludes the roll-call vote of Rep. Ron Estes (R-KS), who took his seat in April.

We also collected data on five independent variables. To examine the influence of intense policy demanders, we first recorded whether members had been identified as part of the HFC or having received campaign contributions from the HFC's political action committee (New York Times2017a). The HFC took a strong stance against the reported version of the AHCA because its tax cuts were, in the HFC's estimation, inadequate. As such, we expected membership in the HFC to be negatively associated with a yes vote on the published whip count that took place after the bill was reported in March. Because the HFC extracted concessions from party leaders in the bargain between MacArthur and Meadows, we expected caucus membership to have no relationship with a yes vote in the roll call vote on May 4, 2017. 
Second, we included a measure of the log dollar value of business contributions in the 2016 election cycle. To be sure, we do not presume that campaign contributions influence members' decisions on rollcall votes (Hall and Wayman 1990). Rather, following Hertel-Fernandez and Skocpol (2015), we treat this measure as an indicator of the strength of the relationship between business contributors and members.

We measured members' ideological preferences with first-dimension DW-NOMINATE scores. We also examined district preferences using the 2017 Cook Partisan Voter Index (PVI), a measurement of how strongly a US congressional district leans toward the Republican Party compared to the rest of the country (Cook Political Report 2017). Higher values of PVI indicate a district's stronger preference for the Republican Party. We expected both conservatism and district-level Republican advantage to be positively and significantly associated with support for the AHCA.

Finally, to measure the effect of ACA repeal on nonelderly individuals within a member's district, we used district-level estimates of nonelderly coverage loss computed by Cutler and Gee (2017), based on the initial CBO analysis. After the AHCA was initially reported in March, these figures were read during debate on the bill by Rep. Frank Pallone (D-NJ; 163 Cong. Rec. H2415 [2017]). These were the only district-level estimates of coverage loss prior to the May 4 roll call, because the vote was scheduled prior to an updated $\mathrm{CBO}$ analysis. Based on current population estimates published by the Census Bureau, we calculated coverage loss as a percentage of the district population. We expected projected coverage losses to be negatively and significantly associated with support for the AHCA.

The results of models explaining the March whip count and the May 4 roll-call vote are presented in table 4. Both models provide support for our hypotheses regarding the role of the HFC in the passage of the AHCA. The results of model 1 (shown in table 3) suggest that membership in the HFC is negatively and significantly associated with support for the version of the AHCA reported in March. The predicted probabilities in table 5 show that membership in the HFC is associated with an 88 percent decrease in the likelihood of support for the AHCA during the whip count. As shown by model 2 presented in table 3 , HFC membership has no statistically significant relationship with House Republicans' roll-call votes on the AHCA. We also estimated models that used an alternative measure of business contributions, restricted to the contributions of business associations (see appendix table A5). Consistent with the results presented in table 4 , business association contributions had no statistically significant effect on the House vote.

Table 4 Logistic Regression Predicting Support for the American Health Care Act, 2017

$\begin{array}{lll}\text { Variable } & \text { Whip count (3/21/17) } & \text { Roll call (5/4/17) } \\ \text { House Freedom Caucus membership } & -3.51(0.56)^{* * *} & -1.04(1.22) \\ \text { Business contributions (Ln. \$) } & -0.04(0.05) & -0.02(0.07) \\ \text { NOMINATE } & 3.88(1.32)^{* *} & 9.21(2.76)^{* * *} \\ \text { Cook Partisan Voter Index } & 0.08(0.02)^{* *} & 0.09(0.04)^{+} \\ \text {Coverage loss } & 0.13(0.09) & 0.06(0.16)\end{array}$


Variable

Log pseudolikelihood

Observations
Whip count $(3 / 21 / 17)$

$-122.34$

237
Roll call (5/4/17)

$-50.80$

237

Notes: Cell entries are logistic regression coefficients with robust standard errors in parentheses. ${ }^{+} p<0.10,{ }^{*} p<0.05,{ }^{* *} p<0.01$, ${ }^{* * *} p<0.001$, two-tailed tests

Table 5 Marginal Effects for Statistically Significant Variables in Models of AHCA Support, 2017

\section{Percent change in predicted probability of support}

\begin{tabular}{|c|c|c|c|}
\hline Independent variable & Change in variable (from, to $)^{a}$ & Whip count & Roll call \\
\hline House Freedom Caucus membership & $0 \rightarrow 1$ & $-88.31 \%$ & - \\
\hline NOMINATE & $0.48 \rightarrow 0.63$ & $10.39 \%$ & $2.07 \%$ \\
\hline Cook Partisan Voter Index & $11.83 \rightarrow 19.59$ & $11.68 \%$ & $1.43 \%$ \\
\hline
\end{tabular}

Note: We calculated marginal effects by shifting variables one standard deviation above the mean for continuous variables and from 0 to 1 for the House Freedom Caucus variable. We held all other variables constant at their mean values or, for the House Freedom Caucus variable, at its modal value.

As expected, conservatism is positively and significantly correlated with support for the AHCA. As table 5 suggests, a shift in NOMINATE from its mean to one standard deviation above its mean (i.e., a member becomes more conservative) increases the likelihood of support for the AHCA by 10 percent in the March whip count and by 2 percent in the roll-call vote. The effect of district preferences is also significant in both models. A shift in PVI from its mean to one standard deviation above its mean (i.e., an increase in Republicans' advantage in the district) increased the likelihood of support for the AHCA by 12 percent in the whip count and by 1 percent in the roll-call vote. Projected district-level coverage losses had no statistically significant effect on a member's support for the AHCA.

\section{Conclusion}

The evidence in this article suggests that intense policy demanders can play an important role in shaping postreform politics. In the case of the ACA, this occurred in two ways. First, intense policy demanders helped define the boundaries of the retrenchment agenda during the early implementation of the ACA. Between 2011 and 2016, House Republicans receiving higher levels of contributions from business associations were significantly more likely to introduce legislation with adverse effects on the ACA. This included legislation that repealed major coverage expansions, as well as financing and administrative provisions intended to support the implementation of the law. It also included legislation intended to increase the level of congressional or executive oversight of the ACA, exposing implementation errors to public scrutiny. Conservatives in the House were also significantly more likely to introduce bills that repealed or obstructed the ACA's major coverage provisions. In other words, while weak policy feedback may have given Republicans an opportunity to engage in retrenchment activity, it is impossible to 
understand the "policy stream" available to advocates of retrenchment without considering the role of intense policy demanders.

Initially, the process of drafting the Republican plan alienated and angered conservative policy experts outside Capitol Hill (Levin 2017; Roy 2017). Instead, the draft version of the AHCA released by Republicans in 2017 bore a striking resemblance to a policy paper published by House leaders in the summer of 2016 (Speaker of the House 2016). The paper itself explicitly drew on hundreds of bills introduced by House Republicans after the enactment of the ACA. Thus, while it is possible that in the absence of intense policy-demander support Republicans would have endorsed repealing and replacing the ACA, it seems unlikely that the policy ideas that dominated the agenda by 2017 would have taken the form they did.

Members introduced fewer bills designed to repeal the ACA after the phase-in of the law's major benefits, yet it seems plausible that this decrease has less to do with policy feedback and more to do with Republicans' convergence on a narrower set of legislative vehicles for repeal. One such vehicle was H.R. 3762, a bill introduced by Rep. Tom Price (R-GA) in 2015. In contrast to prior retrenchment bills, H.R. 3762 emerged from a 212-page House Budget Committee report that attempted to demonstrate that, by preserving some of the ACA's revenue-generating provisions, "repealing Obamacare" would have beneficial fiscal effects (H.Rept. 114-93). The CBO projected that Price's legislation would reduce deficits by $\$ 317$ billion, excluding macroeconomic feedback, and $\$ 516$ billion including those effects (CBO 2015).

Indeed, the influence of intense policy demanders did not seem to diminish after the phase-in of the ACA's benefits. During the debate over the AHCA-House Republicans' proposed repeal-and-replace bill-the HFC exerted sizable leverage, pushing for a more drastic version of repeal that further reduced taxation and spending. Our analysis of a March whip count showed that members of the HFC were 91 percent less likely than other House Republicans to support the original version of the bill. The bill that emerged from negotiations within the Republican caucus included significant cuts to Medicaid and allowed states to waive out of individual market protections introduced by the ACA. More conservative members (i.e., those with a higher NOMINATE score) were more likely to vote in favor of this bill. Projected district-level coverage losses appeared to have no statistically significant effect on House Republican support for the AHCA.

These findings have implications for several avenues of research concerning the ACA itself and for the broader literature on the politics of policy retrenchment. First, our study contributes to research on how partisan and interest group actors have shaped the implementation of the ACA. Whereas prior research illustrates how these actors have shaped the implementation of the ACA at the state level or in the courts, we show that their influence extends to Congress itself (Jones, Bradley, and Oberlander 2013; Béland, Rocco, and Waddan 2014; Haeder and Weimer 2015b). To be sure, Republicans had few major legislative victories on the ACA in the first six years of its implementation. With four years of a Democrat-controlled Senate and six years of President Obama, the opportunities for actual legislative reversal were few. As Redhead and Kinzer (2015) show, Republicans were more successful at more subtle acts of legislative change, including reducing annual appropriations for the administration of the law. Nevertheless, between 2011 and 2016, intense policy demanders spurred the creation of hundreds of policy proposals, many of which were rolled into the development of a more comprehensive plan to repeal and replace the ACA in 2017. 
This article also adds to a growing literature on the role of business organizations and conservative activists in shaping the postenactment politics of health reform. Hertel-Fernandez, Skocpol, and Lynch (2016), for example, show that organizations such as AFP, the American Legislative Exchange Council, and the State Policy Network converged to block Medicaid expansion but often conflicted with state chambers of commerce in doing so. Yet even though ideological conservatives and organized business did not always share the same goals on obstruction of the ACA, our evidence suggests that together they had a significant impact on the legislative agenda at the national level and kept policy efforts focused on the repeal and replacement of the ACA's major coverage expansions.

To be sure, some of the most significant postreform action on the ACA occurred as the result of interactions between Congress and the courts. As Bagley (2016) notes, congressional Republicans made unprecedented use of litigation to prevent the administration from making payments to insurers to reduce out-of-pocket spending of low-income enrollees. Future research should thus investigate how and to what extent retrenchment strategies are coordinated across venues and levels of government, both in the case of the ACA and in other cases. Building on our analysis, additional studies should explore the relationship between agenda setting and the success of retrenchment initiatives. In the case of the ACA, it appears that the influence of intense policy demanders helped push Republicans to make a series of legislative commitments that proved difficult to move through the Senate, even under the budget reconciliation process.

This study also has several implications for theories of postreform politics. Most important, our evidence suggests that theories of retrenchment must consider partisan dynamics that operate independently of policy feedback. As Maltzman and Shipan (2008) note, political conflict can constrain the design of policy in ways that weaken policy durability. Subsequent political conflict can also result in challenges to policy durability. Yet while scholars have identified links between partisan dynamics and the politics of retrenchment, there is a tendency to focus on retrenchment or policy mutation as the outcome of interest. This limits our ability to examine how particular policy ideas gain a place of prominence on the retrenchment agenda. Our evidence bears directly on the question of who set the retrenchment agenda for the ACA and the general approach to retrenchment Republicans have taken thus far. We do not, however, explore why specific policy ideas became central to the AHCA while others were ignored. Building on work by Béland (2007), future research should trace how intense policy demanders shape the content of the policy ideas that define episodes of retrenchment.

For political scientists and policy scholars, the postreform politics of the ACA has produced a kind of intellectual whiplash. Early accounts of the law's enactment made cautiously optimistic predictions: political turbulence notwithstanding, the ACA would land safely among the other social benefits that define the American welfare state. Yet only a short time after implementation began, such predictions gave way to doubts about the law's durability. Both such narratives are grounded in analyses of the law's design and the ramifications of design for the formation of supportive constituencies of voters, interest groups, and bureaucrats. Complementing a growing literature on postreform politics, our evidence suggests that the fortunes of the ACA have thus far been shaped by an element of politics that no policy design could have easily addressed: the asymmetric mobilization of policy demanders within the Republican Party. In short, both policy and party have come to define the "new politics" of health reform. 


\section{Acknowledgments}

We are grateful to Eric Patashnik and the anonymous reviewers for their insightful comments on the draft manuscript. Sahvana Williams and Austin Bohn provided valuable research assistance.

\section{Appendix}

\section{Figure A1}

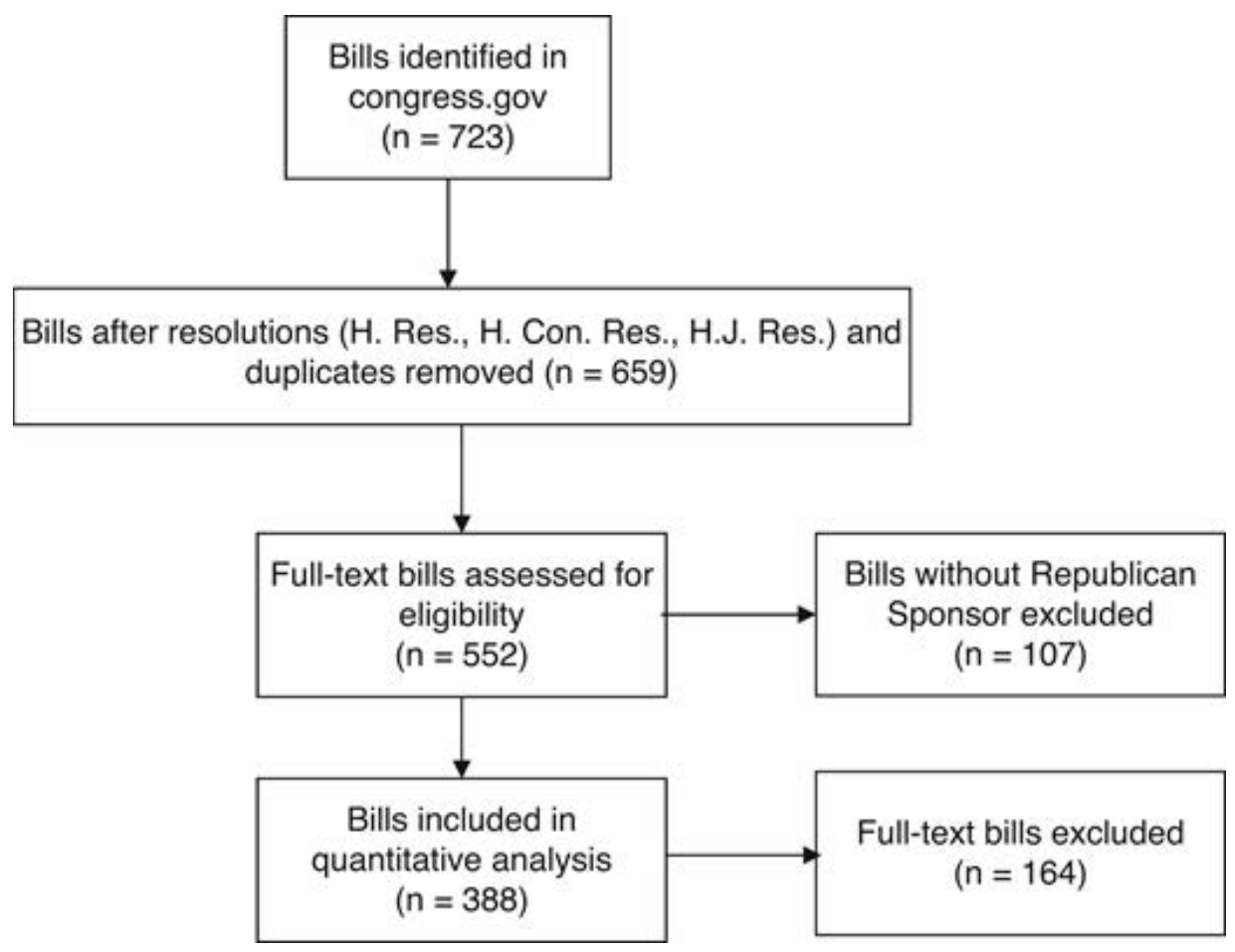

Bill Screening Flow Diagram

Table A1 Americans for Prosperity Key Votes on the Affordable Care Act, 2011-16

\section{Congress Roll Call Chamber Description Number}

\section{\% Republicans Vote type agreeing with AFP position} provisions 


\begin{tabular}{|c|c|c|c|c|c|}
\hline Congress & $\begin{array}{l}\text { Roll Call } \\
\text { Number }\end{array}$ & Chambe & Description & $\begin{array}{l}\text { \% Republicans } \\
\text { agreeing with AFP } \\
\text { position }\end{array}$ & Vote type \\
\hline 112 & 14 & House & Repealing the Job-Killing Health Care Law Act & $100 \%$ & Major repeal \\
\hline 112 & 9 & Senate & $\begin{array}{l}\text { To repeal the "job-killing" health care law and } \\
\text { health-care-related provisions in the Health Care } \\
\text { and Education Reconciliation Act of } 2010\end{array}$ & $100 \%$ & Major repeal \\
\hline 113 & 51 & Senate & Cruz Amendment Repealing ACA & $100 \%$ & Major repeal \\
\hline 113 & 34 & Senate & Cruz-Lee Amendment Repealing ACA & $100 \%$ & Major repeal \\
\hline 114 & 563 & House & $\begin{array}{l}\text { H.R. } 954 \text { - Exemption from paying mandate for } \\
\text { Americans who lost health care coverage }\end{array}$ & $99 \%$ & $\begin{array}{l}\text { Substantive } \\
\text { amendment }\end{array}$ \\
\hline 114 & 351 & House & $\begin{array}{l}\text { H.R. } 1270 \text { - Restoring Access to Medication Act } \\
\text { of } 201\end{array}$ & $95 \%$ & $\begin{array}{l}\text { Substantive } \\
\text { amendment }\end{array}$ \\
\hline 114 & 53 & House & $\begin{array}{l}\text { H.R. } 3762 \text { - To provide for reconciliation } \\
\text { pursuant to section } 2002 \text { of the concurrent } \\
\text { resolution on the budget for fiscal year } 2016 \text {. } \\
\text { (Veto override vote) }\end{array}$ & $98 \%$ & Major repeal \\
\hline 114 & 376 & House & Protecting seniors' access to medication & $95 \%$ & Partial repeal \\
\hline 114 & 375 & House & Protect Medical Innovation Act & $95 \%$ & Partial repeal \\
\hline 114 & 14 & House & Save American Workers Act & $99 \%$ & Major repeal \\
\hline 114 & 58 & House & $\begin{array}{l}\text { H.R. } 596 \text { - Repeal of the President's Healthcare } \\
\text { Law }\end{array}$ & $97 \%$ & Major repeal \\
\hline
\end{tabular}

Source: Authors' analysis of Americans for Prosperity Scorecards published at afpscorecard.org

Table A2 Average Republican Support for Americans for Prosperity Key Vote Positions, by Congress and Issue Area, 2007-16 (\%)

$\begin{array}{llll}\text { Congress } & \text { Health care and entitlements } & \text { Taxes } & \text { Budget and spending } \\ 110 & 81 & 89 & 50 \\ 111 & 96 & 81 & 95\end{array}$




$\begin{array}{llll}\text { Congress } & \text { Health care and entitlements } & \text { Taxes } & \text { Budget and spending } \\ 112 & 99 & 67 & 70 \\ 113 & 100 & 59 & 67 \\ 114 & 97 & 98 & 68\end{array}$

Source: Authors' analysis of Americans for Prosperity Scorecards published at afpscorecard.org

Table A3 Negative Binomial Regression Predicting Number of ACA-Related Bill Introductions by House Republicans, 2011-16 (Alternative Measure of Business Contributions)

Variable

Business association contributions ( $\operatorname{Ln} . \$) 0$.

All bills Major repeals

Partial repeals

Amendments Oversight/audit

\begin{tabular}{|c|c|c|c|c|c|}
\hline & $(0.02)^{* *}$ & $(0.04)^{* *}$ & $(0.05)$ & $(0.03)$ & $(0.04)$ \\
\hline \multirow[t]{2}{*}{ NOMINATE } & 0.74 & 3.23 & 1.09 & -0.39 & -0.52 \\
\hline & $(0.41)^{+}$ & $(0.80)^{* * *}$ & $(0.89)$ & $(0.62)$ & $(0.98)$ \\
\hline \multirow[t]{2}{*}{ Seniority } & 0.00 & 0.06 & -0.03 & -0.01 & 0.01 \\
\hline & $(0.02)$ & $(0.03)^{*}$ & $(0.04)$ & $(0.02)$ & $(0.04)$ \\
\hline \multirow[t]{2}{*}{ Committee member } & 0.52 & -0.36 & 0.92 & 0.77 & 0.38 \\
\hline & $(0.18)^{* *}$ & $(0.42)$ & $(0.33)^{* *}$ & $(0.25)^{* *}$ & $(0.42)$ \\
\hline \multirow[t]{2}{*}{ Health subcommittee member } & 0.45 & 1.17 & 0.20 & 0.37 & 0.41 \\
\hline & $(0.19)^{*}$ & $(0.43)^{* *}$ & $(0.33)$ & $(0.27)$ & $(0.45)$ \\
\hline \multirow[t]{2}{*}{ Committee leadership } & 0.03 & -0.26 & 0.71 & -0.25 & 0.02 \\
\hline & $(0.20)$ & $(0.47)$ & $(0.36)^{*}$ & $(0.30)$ & $(0.49)$ \\
\hline \multirow[t]{2}{*}{ Sponsorship activity } & 0.04 & 0.03 & 0.02 & 0.05 & 0.03 \\
\hline & $(0.01)^{* * *}$ & $(0.01)^{* *}$ & $(0.01)^{*}$ & $(0.01)^{* * *}$ & $(0.01)^{*}$ \\
\hline \multirow[t]{2}{*}{ Uninsured rate } & 0.01 & -0.00 & 0.01 & 0.00 & 0.02 \\
\hline & (01) & $(0.02)$ & $(0.02)$ & $(0.02)$ & $(0.02)$ \\
\hline \multirow[t]{2}{*}{ 113th Congress } & 0.48 & -0.04 & -0.01 & 1.03 & 1.01 \\
\hline & $(0.14)^{* * *}$ & $(0.26)$ & $(0.29)$ & $(0.23)^{* * *}$ & $(0.36)^{* *}$ \\
\hline \multirow[t]{2}{*}{ 114th Congress } & -0.08 & -0.78 & -0.31 & 0.45 & 0.31 \\
\hline & $(0.15)$ & $(0.31)^{*}$ & $(0.30)$ & $(0.25)^{+}$ & $(0.40)$ \\
\hline Alpha & 0.43 & 0.75 & 0.52 & 0.60 & 0.89 \\
\hline Log likelihood & -659.61 & -257.43 & -233.62 & -380.04 & -195.98 \\
\hline
\end{tabular}


Variable

Observations (clusters)
All bills Major repeals Partial repeals Amendments Oversight/audit

$\begin{array}{lllll}730 & 730 & 730 & 730 & 730 \\ (330) & (330) & (330) & (330) & (330)\end{array}$

Notes: Cell entries are coefficients from negative binomial regression with clustered standard errors in parentheses. ${ }^{+} p<0.10$, ${ }^{*} p<0.05,{ }^{* *} p<0.01,{ }^{* * *} p<0.001$, two-tailed tests

Table A4 Negative Binomial Regression Predicting Number of ACA-Related Bill Introductions by House Republicans, 2011-16 (Reduced Models)

$\begin{array}{llllll}\text { Variable } & \text { All bills } & \text { Major repeals } & \text { Partial repeals } & \text { Amendments } & \text { Oversight } \\ \text { Business contributions (Ln. \$) } & 0.37 & 0.52 & 0.52 & 0.21 & 0.66 \\ & (0.09)^{* * *} & (0.17)^{* *} & (0.19)^{* *} & (0.11)^{*} & (0.21) \\ \text { NOMINATE } & 0.71 & 3.44 & 0.94 & -0.66 & 0.08 \\ & (0.43)^{+} & (0.83)^{* * *} & (0.88) & (0.63) & (0.99) \\ \text { Alpha } & 0.96 & 1.43 & 2.08 & 1.53 & 1.51 \\ \text { Log likelihood } & -707.67 & -273.86 & -252.39 & -415.55 & -205.17 \\ & & & & & 730 \\ \text { Observations (clusters) } & 730 & 730 & 730 & 730 & (330)\end{array}$

Notes: Cell entries are coefficients from negative binomial regression with clustered standard errors in parentheses. ${ }^{+} p<0.10$, ${ }^{*} p<0.05,{ }^{* *} p<0.01,{ }^{* * *} p<0.001$, two-tailed tests

Table A5 Logistic Regression Predicting Support for the American Health Care Act, 2017 (Alternative Measure of Business Contributions)

Variable

House Freedom Caucus membership

Business association contributions (In. \$)

NOMINATE

Cook Partisan Voter Index

Coverage loss

Log pseudolikelihood

Observations
Whip count

(3/21/17)

$-3.39(0.56)^{* * *}$

$0.05(0.04)$

$3.91(1.32)^{* *}$

$0.08(0.02)^{* * *}$

$0.13(0.09)$

$-122.22$

237
Roll call

$(5 / 4 / 17)$

$-0.97(1.22)$

$0.02(0.08)$

$9.25(2.75)^{* * *}$

$0.09(0.04)^{+}$

$0.06(0.16)$

$-50.76$ 
Notes: Cell entries are coefficients from logistic regression with robust standard errors in parentheses. ${ }^{+} p<0.10,{ }^{*} p<0.05$, ${ }^{* *} p<0.01,{ }^{* * *} p<0.001$, two-tailed tests

\section{Notes}

1. This view contrasts with the conventional perspective of political parties as "teams" of politicians who seek to win and hold political office (Downs 1957).

2. As Hertel-Fernandez, Skocpol, and Lynch (2016) show, state chambers of commerce were divided on the ACA's Medicaid expansion. Indeed, state chamber endorsement for Medicaid expansion was associated with a higher probability of gubernatorial support.

3. While DW-NOMINATE scores are a defensible and widely used measure of legislator ideology, Lee (2016) has recently suggested that NOMINATE taps into party and ideology simultaneously and may yield a measure of ideology extremity even for members who are simply "party regulars." This cautions against interpreting the relationship between NOMINATE scores and bill introductions as a test of how ideological extremity alone affects bill sponsorship behavior.

4. A revised $\mathrm{CBO}$ analysis of the $A H C A$ including the MacArthur Amendment, published after the House passed the bill, revised this estimate down to 23 million. See CBO 2017b.

\section{References}

Akron Beacon Journal. 2017.Their 'Very, Very Bad Idea' for the Medicaid Expansion." March 11.

Alberta, Tim. (2017). "Inside the GOP's Healthcare Debacle." Politico, March 24.

American Medical Association. (2017). "AMA Vision on Health Reform," www.ama-assn.org/ama-healthreform-vision (accessed August 1, 2017).

AFP (Americans for Prosperity). (2017a). "AFP Grassroots Convenes on U.S. Capitol at Obamacare Repeal Rally." AFP, March 8.

AFP (Americans for Prosperity). (2017b). Americans for Prosperity Legislative Scorecard. afpscorecard.org/ (accessed May 30, 2017).

Bade Rachel. (2015). “Obamacare Repeal Still Vexes GOP.” Politico, June 23.

Bade, Rachel, and Dawsey, Josh. (2017). "The White House Just Couldn't Let This Go." Politico, May 5.

Bagley, Nicholas. (2016). "A Legal Setback for the Affordable Care Act." New England Journal of Medicine 374, no. 24: 2307-09.

Bawn, Kathleen, Cohen, Martin, Karol, David, Masket, Seth, Noel, Hans, and Zaller, John. (2012). "A Theory of Political Parties: Groups, Policy Demands and Nominations in American Politics." Perspectives on Politics 10: 571-97.

Beaussier, Anne-Laure. (2012). "The Patient Protection and Affordable Care Act: The Victory of Unorthodox Lawmaking." Journal of Health Politics, Policy and Law 37:741-78.

Béland, Daniel. (2007). "Ideas and Institutional Change in Social Security: Conversion, Layering, and Policy Drift." Social Science Quarterly 88, no. 1:20-38.

Béland, Daniel, Rocco, Philip, and Waddan, Alex. (2014). "Implementing Health Care Reform in the United States: Intergovernmental Politics and the Dilemmas of Institutional Design." Health Policy 116: 51-60.

Béland, Daniel, Rocco, Philip, and Waddan, Alex. (2015). "Polarized Stakeholders and Institutional Vulnerabilities: The Enduring Politics of the Patient Protection and Affordable Care Act." Clinical Therapeutics 37: 720-26. 
Béland, Daniel, Rocco, Philip, and Waddan, Alex. (2016). Obamacare Wars: Federalism, State Politics, and the Affordable Care Act. Lawrence University Press of Kansas.

Berry, Christopher R., Burden, Barry C., and Howell, William G. (2010). "After Enactment: The Lives and Deaths of Federal Programs," American Journal of Political Science 54:1-17.

Bloch Rubin, Ruth. (2013). "Organizing for Insurgency: Intraparty Organization and the Development of the House Insurgency, 1908-1910." Studies in American Political Development 27: 86-110.

Broockman, David E., Carnes, Nicholas, Crowder-Meyer, Melody, and Skovron, Christopher. (2017). "Having Their Cake and Eating It, Too: (Why) Local Party Leaders Prefer Nominating Extreme Candidates." Working Paper. Palo Alto, CA: Stanford University.

Campbell, Andrea Louise. (2011). "Policy Feedbacks and the Impact of Policy Designs on Public Opinion." Journal of Health Politics, Policy and Law. 36: 961-73.

CBO (Congressional Budget Office). (2015). "Estimate of Direct Spending and Revenue Effects of H.R. 3762." Washington, DC: CBO.

CBO (Congressional Budget Office). (2017a). “Cost Estimate: American Health Care Act." March 13. www.cbo.gov/publication/52486.

CBO (Congressional Budget Office). (2017b). "H.R. 1628, American Health Care Act of 2017: Cost Estimate." May 24. www.cbo.gov/publication/52752.

Collier, David. (2011). "Understanding Process Tracing." PS: Political Science and Politics 44: 823-30.

Cook Political Report. (2017). "Cook Partisan Voting Index." cookpolitical.com/story/10304 (accessed March 17, 2017).

Cox, Cynthia, Claxton, Gary, and Levitt, Larry. (2017). How Affordable Care Act Repeal and Replace Plans Might Shift Health Insurance Tax Credits, March 10. www.kff.org/health-reform/issuebrief/how-affordable-care-act-repeal-and-replace-plans-might-shift-health-insurance-taxcredits/.

Cutler, David, and Gee, Emily. (2017). "Coverage Losses by Congressional District under the House ACA Repeal Bill." March 17.

www.americanprogress.org/issues/healthcare/news/2017/03/17/428601/coverage-lossescongressional-district-house-aca-repeal-bill/.

DiJulio, Bianca, Firth, Jamie, and Brodie, Mollyann. (2015). “Kaiser Health Tracking Poll: June 2015." June 16. www.kff.org/health-costs/poll-finding/kaiser-health-tracking-poll-june-2015/.

DiSalvo, Daniel. (2012). Engines of Change: Party Factions in American Politics, 1868-2010. New York: Oxford University Press.

Downs, Anthony. (1957). An Economic Theory of Democracy. New York: Harper Collins.

Fenno, Richard. (2003). Home Style: House Members in their Districts. New York: Longman.

George, Alexander L., and Bennett, Andrew. (2005). Case Studies and Theory Development in the Social Sciences. Cambridge, MA: MIT Press.

Gerber, Alan S., and Schickler, Eric, eds. (2017). Governing in a Polarized Age: Elections, Parties, and Political Representation in America. New York: Cambridge University Press.

Gerring, John. (2004). "What Is a Case Study and What Is It Good For?" American Political Science Review. 98: 341-54.

Hacker, Jacob S. (2004). "Privatizing Risk without Privatizing the Welfare State: The Hidden Politics of Social Policy Retrenchment in the United States." American Political Science Review 98: 243-60.

Haeder, Simon F. (2012). "Beyond Path Dependence: Explaining Healthcare Reform and Its Consequences." Policy Studies Journal 40: 65-86. 
Haeder, Simon F., and Weimer, David L. (2013). "You Can't Make Me Do It: State Implementation of Insurance Exchanges under the Affordable Care Act." Public Administration Review 73: S34-47.

Haeder, Simon F., and Weimer, David L. (2015a). "Inching toward Universal Coverage: State-Federal Health-Care Programs in Historical Perspective." Journal of Public History 27: 746-70.

Haeder, Simon F., and Weimer, David L. (2015b). "You Can't Make Me Do It, but I Could Be Persuaded: A Federalism Perspective on the Affordable Care Act." Journal of Health Politics, Policy and Law 40: 281-323.

Hall, Richard L., and Wayman, Frank W. (1990). "Buying Time: Moneyed Interests and the Mobilization of Bias in Congressional Committees." American Political Science Review 84: 797-820.

Harrington, Rebecca. (2017). "Billionaire Koch Brothers Are Promising Millions to Republicans That Help Sink 'Trumpcare.'” Business Insider, March 23.

Hertel-Fernandez, Alexander. 2014. "Who Passes Business's 'Model Bills'? Policy Capacity and Corporate Influence in US State Politics." Perspectives on Politics 12: 582-602.

Hertel-Fernandez, Alexander, and Theda Skocpol. 2015. "Asymmetric Interest Group Mobilization and Party Coalitions in US Tax Politics." Studies in American Political Development 29, no. 2: 235-49.

Hertel-Fernandez, Alexander, Theda Skocpol, and Daniel Lynch. 2016. "Business Associations, Conservative Networks, and the Ongoing Republican War over Medicaid Expansion." Journal of Health Politics, Policy and Law 41: 239-86.

Herzenshorn, David M. 2015. "Not Even Catharsis Is Seen in Senate Vote to Repeal Health Law." New York Times, December 4.

Himelfarb, Richard. 1995. Catastrophic Politics: The Rise and Fall of the Medicare Catastrophic Coverage Act of 1988. University Park: Pennsylvania State University Press.

Jacobs, Alan M., and R. Kent Weaver. 2015. "When Policies Undo Themselves: Self-Undermining Feedback as a Source of Policy Change." Governance 28: 441-57.

Jacobs, Lawrence R., and Timothy Callaghan. 2013. "Why States Expand Medicaid: Party, Resources, and History." Journal of Health Politics, Policy and Law 38: 1024-50.

Jones, David K., Katharine W. V. Bradley, and Jonathan Oberlander. 2013. "Pascal's Wager: Health Insurance Exchanges, Obamacare, and the Republican Dilemma." Journal of Health Politics Policy and Law 39: 97-137.

Jost, Timothy S. 2017. "The MacArthur Amendment Language, Race in the Federal Exchange, and Risk Adjustment Coefficients." Health Affairs Blog, April 25. www.healthaffairs.org/do/10.1377/hblog20170426.059819/full/.

Kaiser Family Foundation. 2017. "Premiums and Tax Credits under the Affordable Care Act vs. the American Health Care Act: Interactive Maps." www.kff.org/interactive/tax-credits-under-theaffordable-care-act-vs-replacement-proposal-interactive-map/ (accessed April 27, 2017).

Kelly, Andrew. 2017. "Health Reform in the Trump Era: Will Politics Unmake Politics?" Forum 15: 34562.

Lazarus, Jeffrey. 2013. "Issue Salience and Bill Introduction in the House and Senate." Congress and the Presidency 40: 215-29.

Lee, Frances E. 2016. "Patronage, Logrolls, and 'Polarization': Congressional Parties of the Gilded Age, 1876-1896." Studies in American Political Development 30:116-27.

Levin, Yuval. 2017. "The House Should Slow Down and Fix the GOP Health-Care Bill." National Review, March 15. 
Lincoln Journal Star. 2017. "Many Reasons for Outrage in Health Bill." March 8. Mahoney, James, and Kathleen Thelen. 2010. Explaining Institutional Change: Ambiguity, Agency, and Power. New York: Cambridge University Press.

Maltzman, Forrest, and Charles R. Shipan. 2008. "Change, Continuity, and the Evolution of the Law." American Journal of Political Science 52: 252-67.

Mettler, Suzanne. 2011. The Submerged State: How Invisible Government Policies Undermine American Democracy. Chicago: University of Chicago Press.

NFIB (National Federation of Independent Business). 2012. "How Congress Voted, 112th Congress." www.nfib.com/Portals/O/PDF/AllUsers/issuesElections/how-congress-voted-112th-nfib.pdf (accessed June 10, 2017).

NFIB (National Federation of Independent Business). 2014. "How Congress Voted, 113th Congress." www.nfib.com/assets/HCV.pdf (accessed June 10, 2017).

NFIB (National Federation of Independent Business). 2016. "How Congress Voted, 114th Congress Preelection Report." www.nfib.com/assets/How-Congress-Voted-Pre-election-Report-Web.pdf (accessed June 10, 2017).

Needham, Michael. 2017. "GOP Plan Fails to Move Past Obamacare's Progressive Promise." Heritage Action for America, March 7.

New York Times. 2017a. "How Every Member Voted on the House Health Care Bill." May 4.

New York Times. 2017b. "How House Republicans Planned to Vote on the Obamacare Replacement." March 21.

Oberlander, Jonathan. 2007. "Through the Looking Glass: The Politics of the Medicare Prescription Drug, Improvement, and Modernization Act." Journal of Health Politics, Policy and Law 32: 187-219.

Oberlander, Jonathan, and R. Kent Weaver. 2015. "Unraveling from Within? The Affordable Care Act and Self-Undermining Policy Feedbacks." Forum 13: 37-62.

Orren, Karen, and Stephen Skowronek. 2017. The Policy State: An American Predicament. Cambridge, MA: Harvard University Press.

Patashnik, Eric M. 2008. Reforms at Risk: What Happens after Major Policy Changes Are Enacted. Princeton, NJ: Princeton University Press.

Patashnik, Eric M., and Julian E. Zelizer. 2013. "The Struggle to Remake Politics: Liberal Reform and the Limits of Policy Feedback in the Contemporary American State." Perspectives on Politics 11: 1071-87.

Pear, Robert. 2016. "Tom Price: H.H.S. Nominee, Drafted Remake of Health Law." New York Times, November 29. www.nytimes.com/2016/11/29/us/tom-price-trump-health-secretary.html

Pierson, Paul. 2000. "Not Just What, but When: Timing and Sequence in Political Processes." Studies in American Political Development 14: 72-92.

Poole, Keith, and Howard Rosenthal. 2011. Ideology and Congress. New Brunswick, NJ: Transaction.

Redhead, C. Stephen, and Janet Kinzer. 2015. "Legislative Actions to Repeal, Defund, or Delay the Affordable Care Act." Congressional Research Service, September 22. edworkforce.house.gov/uploadedfiles/crs__legislative_actions_to_repeal_defund_or_delay_the_aca.pdf.

Rocca, Michael S., and Stacy B. Gordon. 2010. "The Position-Taking Value of Bill Sponsorship in Congress." Political Research Quarterly 63: 387-97.

Rocco, Philip, and Chloe Thurston. 2014. "From Metaphors to Measures: Observable Indicators of Gradual Institutional Change." Journal of Public Policy 34: 35-62 
Rose, Shanna. 2013. Financing Medicaid: Federalism and the Growth of America's Health Care Safety Net. Ann Arbor: University of Michigan Press.

Roy, Avik. 2017. "The Path Forward for Replacing Obamacare." National Review, March 28.

Ryan, Paul. 2016. "Special Report with Bret Baier." Fox News, November 10. insider.foxnews.com/2016/11/10/paul-ryan-special-report-donald-trump-republican-congress.

Schiller, Wendy J. 1995. "Senators as Political Entrepreneurs: Using Bill Sponsorship to Shape Legislative Agendas." American Journal of Political Science 39:186-203

Skocpol, Theda, and Alexander Hertel-Fernandez. 2016. "The Koch Network and Republican Party Extremism." Perspectives on Politics 14: 681-99.

Speaker of the House. 2016. "A Better Way: Health Care." June 22. abetterway.speaker.gov/_assets/pdf/ABetterWay-HealthCare-PolicyPaper.pdf.

Stewart, Charles, and Jonathan Woon. 2017. "Congressional Committee Assignments, 103rd to 114th Congresses, 1993-2017." web.mit.edu/17.251/www/data_page.html\#2 (accessed May 1, 2017).

St. Louis Post-Dispatch. 2017. "By Any Name, the Republican Health Care Plan Is a Mess." March 9.

Tomz, Michael, and Robert P. Van Houweling. 2012. "Political Pledges as Credible Commitments." Unpublished ms., Stanford University.

USCC (US Chamber of Commerce). 2011a. How They Voted, 2011 (House). www.uschamber/com/howthey-voted-2011-house (accessed September 1, 2017).

USCC (US Chamber of Commerce). 2011b. How They Voted, 2011 (Senate). www.uschamber/com/howthey-voted-2011-senate (accessed September 1, 2017).

USCC (US Chamber of Commerce). 2012a. How They Voted, 2012 (House). www.uschamber/com/howthey-voted-2012-house (accessed September 1, 2017).

USCC (US Chamber of Commerce). 2012b. How They Voted, 2012 (Senate). www.uschamber/com/howthey-voted-2012-senate (accessed September 1, 2017).

USCC (US Chamber of Commerce). 2013a. How They Voted, 2013 (House). www.uschamber/com/howthey-voted-2013-house (accessed September 1, 2017).

USCC (US Chamber of Commerce). 2013b. How They Voted, 2013 (Senate). www.uschamber/com/howthey-voted-2013-senate (accessed September 1, 2017).

USCC (US Chamber of Commerce). 2014a. How They Voted, 2014 (House). www.uschamber/com/howthey-voted-2014-house (accessed September 1, 2017).

USCC (US Chamber of Commerce). 2014b. How They Voted, 2014 (Senate). www.uschamber/com/howthey-voted-2014-senate (accessed September 1, 2017).

USCC (US Chamber of Commerce). 2015a. How They Voted, 2015 (House). www.uschamber/com/howthey-voted-2015-house (accessed September 1, 2017).

USCC (US Chamber of Commerce). 2015b. How They Voted, 2015 (Senate). www.uschamber/com/howthey-voted-2015-senate (accessed September 1, 2017).

USCC (US Chamber of Commerce). How They Voted, 2016. www.uschamber.com/how-they-voted/2016 (accessed September 1, 2017).

Weir, Margaret. 2006. "When Does Politics Create Policy? The Organizational Politics of Change." In Rethinking Political Institutions: The Art of the State, edited by lan Shapiro, Stephen Skowronek, and Daniel Galvin, 171-86. New York: New York University Press.

Woon, Jonathan. 2009. "Issue Attention and Legislative Proposals in the US Senate." Legislative Studies Quarterly 34: 29-54. 